Copyright (C) 2019 by Academic Publishing House Researcher

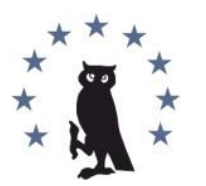

Published in the Russian Federation

European Researcher. Series A

Has been issued since 2010.

E-ISSN 2224-0136

2019, $10(1): 38-49$

DOI: 10.13187/er.2019.1.38

www.erjournal.ru

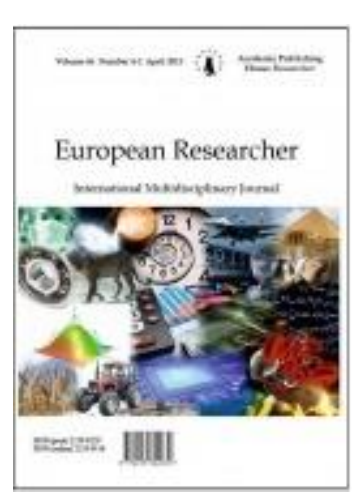

\title{
Land Rights as Social Rights: A Micro-Level Study
}

\author{
Sribas Goswami a * \\ a Serampore College, Hooghly, West Bengal, India
}

\begin{abstract}
Displacement constitutes a major human problem in India. It dislocates People from their home, land \& environment \& has traumatic consequences for their lives. Displacement can be caused by natural calamities such as flood, cyclone, tsunami, earthquake \& manmade factors such as political conflict, wars \& social strife. Development process, also man-made, has been added to the third source. While the first two causes have been a recurring phenomenon in the evolution of civilization, the third cause has emerged from the efforts of governments to modernize traditional societies. Of the three, the first two categories of displacement are unplanned \& usually unanticipated. The third category of displacement, however, is the result of prior \& conscious planning \& therefore anticipated. Of the two categories of unplanned displacement, the one that is due to natural calamities is usually of a shorter duration while the rather arising out of war, political conflict, \& social strife may have a little longer duration \&, in some situations, even of a permanent nature if the issues giving rise to it do not set satisfactorily resolved. But displacement from development projects such as open cast coal mining is invariably permanent. This is because contemporary development is associated with big projects requiring huge areas of land, such as dams, airports, extraction of minerals, industrial plants, provisions of social service, housing etc. Present study finds the multifaceted problems of land acquisition for expansion of existing coal mines as well as establishment of new mining establishment in West Burdwan district of West Bengal, India.
\end{abstract}

Keywords: coal mining, displacement, land acquisition, discrimination, environment.

\section{Introduction}

Economic liberalization continues to create desire for space to meet the demands of industrialization, infrastructure building, urban expansion etc. Balancing these conflicting objectives is one of the utmost challenges that our policymakers are facing. Land acquisition has become a most distressing problem for policymakers as well as for politicians in India. The prominent role of governments across the developing world in acquiring agricultural land on behalf of industrial entrepreneurs has gained a lot of attention recently.

The rapid population expansion of West Bengal also has not been accompanied by considerable economic growth. Local politicians, in many situations, gained power by promising agricultural land to landless farmers. But given West Bengal's population density \& fragmented nature of land-holdings, yields are insufficient to sustain poor families. Shift from agriculture to industrial jobs provides an opportunity for earning higher income. One of the main points that

\footnotetext{
${ }^{*}$ Corresponding author

E-mail addresses: sribasgoswami@gmail.com (S. Goswami)
} 
have been emphasized in favour of industrialization is that it is the obvious next step to the government's intervention in agriculture, building on the benefits of land reforms. From this stand point it (land acquisition) can be viewed merely as a continuation of the earlier land policy of the state rather than a major change in course. Though in several cases there has been stiff resistance to these state-sponsored acquisitions by peasants and agricultural labourers whose livelihood is threatened by the conversion of agricultural land for industry, infrastructure or real estate. Due to unprecedented media and public concern names like Singur, Nandigram, Kalinganagar are now well known to all. The findings of this project are to present the problems of land acquisition for new industrial establishment, mining-induced displacement and resettlement occurring in different regions of India, as a highly diverse national socioeconomic issue. It is a source of challenges to public law and institutions providing humanitarian assistance as well as a matter of deep concern for human rights. This study will focus on various dimensions of bulk land acquisition cases in Southern Bengal and problems associated with it. It will also try to probe into the deep of land acquisition policy of state government and people's reaction on land acquisition for establishment of new industry as well as extension of existing industry. Displacement constitutes a major human problem in India. It dislocates People from their home, land \& environment \& has traumatic consequences for their lives. Displacement can be caused by natural calamities such as flood, cyclone, tsunami, earthquake \& manmade factors such as political conflict, wars \& social strife. Development process, also man-made, has been added to the third source. While the first two causes have been a recurring phenomenon in the evolution of civilization, the third cause has emerged from the efforts of governments to modernize traditional societies. Of the three, the first two categories of displacement are unplanned \& usually unanticipated. The third category of displacement, however, is the result of prior \& conscious planning \& therefore anticipated. Of the two categories of unplanned displacement, the one that is due to natural calamities is usually of a shorter duration while the rather arising out of war, political conflict, \& social strife may have a little longer duration \&, in some situations, even of a permanent nature if the issues giving rise to it do not set satisfactorily resolved. But displacement from development projects is invariably permanent. This is because modern development is associated with big projects requiring huge areas of land, such as dams, airports, extraction of minerals, industrial plants, housing, provision of social service, etc. Since huge chunks of vacant land at a particular location on are available in rural areas only, though already under productive use by and large, it is the people in rural areas subsisting on these lands who bear the brunt of acquisition for them. As a result of this acquisition, the persons affected by $t$ are shifted to alternative location. The acquisition of land is carried out in a specified manner under a law which empowers the state to do so even without the consent of affected persons in public interest though a limited opportunity is given to them to raise any objection and the acquisition authority is required to compensate the land losers for this loss. Altogether, this exercise is heavily tilted in favour of the state which has overriding powers to take over the desired land, if necessary, by using force. Thus, the land acquisition is gradually more becoming a coercive operation lacking in sensitivity to human consequences involved in trail if devastation and trauma it leaves behind. There are several laws, central and state, under which land is acquired. While most other laws confine the acquisition for a specified sector of 'public purpose' such as coal mines, atomic energy, post and telegraph, highways, town planning, bulk of the acquisition takes place under the Land Acquisition Act, 1894 which applies to acquisition for any 'public purpose' and also provides the general structural framework for it. The law was enacted by the colonial government along with the Indian Forest Act, 1865 to have control over natural resources of the country for their commercial exploitation. The acquisition law has continued to be used by the government after Independence for diverse development activities. This has led to the displacement of a large number of persons from their land, habitat and livelihood. The changes made in the Act in 1984 extended its use to acquisition of land for companies, public and private including registered societies and cooperatives, as well which added to the scope of acquisition. The shift to a neo-liberal economy and its integration with the global economic order has widened the scale of acquisition of land and accelerated its pace. The enactment of Special Economic Zone (SEZ) Act, 2005 has brought a new dimension to the demand for acquisition of land in terms of area, location, size and geographical spread. The resistance to such acquisition has been spontaneous and widespread the government has responded with use of force to suppress this opposition. In the discourse on the political 
economy of land acquisition, the existing Act has come in for a very sharp attack on grounds of its conflict with democratic ethos and considerations of equity and social justice. The economic rationality, environmental compatibility and moral propriety of large scale acquisition of land have also been questioned. There has been a long pending demand for drastic changes in the law and even for its abrogation and several suggestions have been made on the nature of changes required to be incorporated in the formulation of new proposals. The public discourse on land acquisition has thrown up a rich material on how the architecture of the existing Act and its contents hurt the affected people (Polanyi, 1944). Several issues have been raised in this discourse ranging from conceptual to operational, structural and those relating to governance. The subject brings centre stage an old issue of political theory - state's relationship with its citizens. The existing law is built on the construction of this relationship as viewed from the interests of a colonial government whose only concern was to have total control over natural resources of a colony which were hitherto under use of the communities as per their customary practices to facilitate their exploitation for serving the interests of the mother country. Being an undemocratic state, it did not bother how the law it enacted would impact the people affected by it. With this sole objective, it enacted two major legal instruments. The one appropriated the forest converting it into state property and extinguishing/curtailing customary entitlements of the local communities to access its resources. It also took over its management depriving local communities of any say in the matter. The second brought on the statute book a law to take over privately occupied land thereby depriving its users of livelihood, displacing them from their habitat, environment and social networks, limiting their choices in life and forcing them to accepting consequences that were highly detrimental to their dignified existence. The only conditionality that the law imposed in the exercise of this power was that a larger public good should guide this action and land losers should receive financial compensation. This change was achieved by decimating community and its control and management of resources, radically altering the contours of individual entitlements and tilting the balance of relationship overwhelmingly in favour of the state. The new relationship that crafted was by the law and continued, rather reinforced, by the postcolonial state is not only antithetical to democracy but also the negation of humanism and social justice. The expanded ambit of land acquisition law and the enormity of its application in independent India further tilted the relationship against citizens, without being checkmated by constitutional provisions, participatory institutions, vibrant judiciary and the prescriptions contained in international conventions and instruments (Upadhyay, 2009).

\section{Objectives of the Study}

1. To study the socio - economic impact of the land acquisition on rural people. For this purpose we include those whose primary occupation is agricultural and non- agricultural work, in order to gauge the effect of the acquisition on these groups as well.

2. To examine the changes in employment status of the affected people in pre \& post acquisition scenario. land.

3. To focus on the types of compensation offered by the state government to the owners of

4. To see how the compensation is being used (where it is already done).

5. To assess the impact of displacement in living standard of the people involved.

7. To make recommendations on the basis of the findings of the study. Those recommendations are expected to be very helpful in Government's policy making.

\section{Methodology of the study}

For the proposed work the area of the study is South Bengal which includes 1 district namely west Burdwan which has the highest concentration of several industries in West Bengal, India. Both descriptive and analytical approach is proposed for the study. As a tool an interview schedule is prepared to collect primary information from the people. Other distracts like Birbhum and Bankura have been visited for study.

The study mainly depends on direct intensive observation and interviews with individuals affected by land acquisition. The demographic and economic surveys are conducted among all the households with the help of structured and open-ended questionnaire schedules. The qualitative information regarding the feeling and attitude of the acquisition of the affected persons are 
collected through repeated conversations with those persons over long period of time. The stories of hardship and economic crisis are addressed from individual family members by the case study method. Apart from the above mentioned field study, the earlier published and unpublished field materials collected from different sources are used in this study.

a. Quantitative Methods

- Land Acquisition Survey (persons with titles, those without titles and others including tenants, sharecroppers should all be counted)

- Census Survey

- Socioeconomic Survey (This should involve only a percentage of total population selected on a random basis)

- Other administrative records (such as NSS)

b. Qualitative Methods

- Key Informant Interviews

- Focus Group Discussions (FGDs)

\section{Findings and observations}

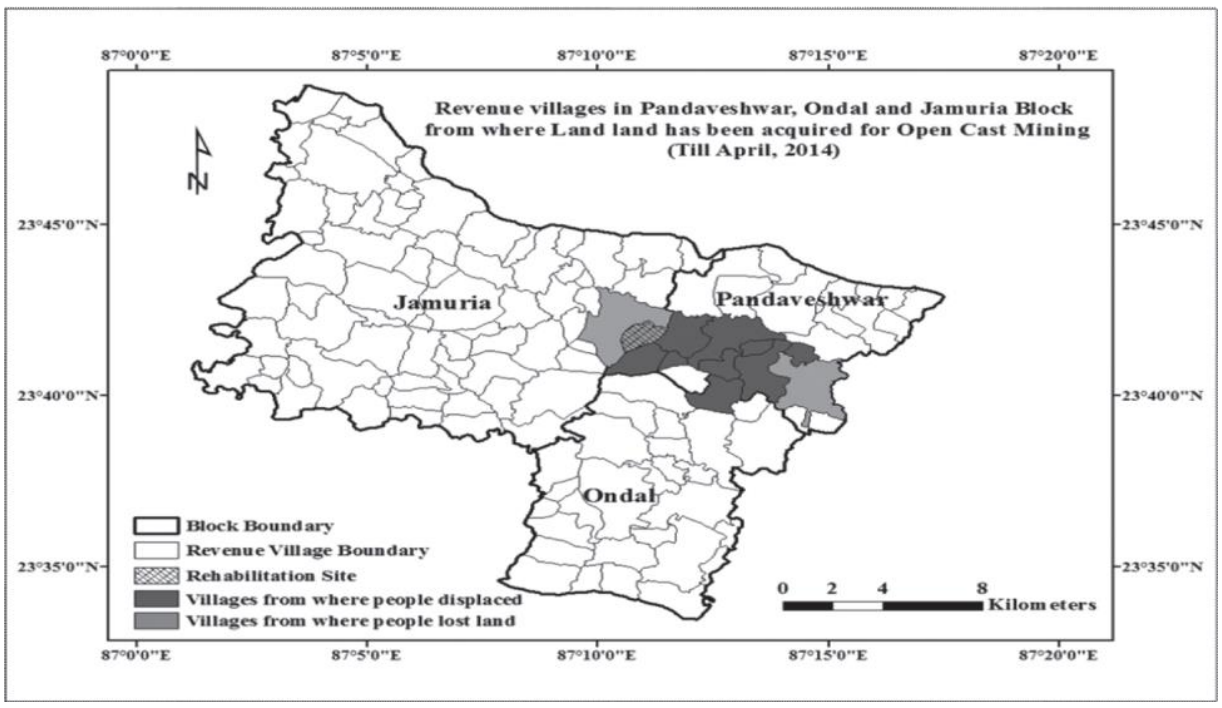

Fig. 1. Revenue villages in Pandaveshwar, Ondal and Jamuria blocks from where land has been acquired for open cast mining (Till April, 2017)

Source: CMPDIL, 2017 (Village Boundary Map).

Table 1. Rehabilitation \& Resettlement in Sonpur Bazari

\begin{tabular}{|c|c|c|c|c|c|}
\hline \multirow{2}{*}{$\begin{array}{l}\text { Sl. } \\
\text { No }\end{array}$} & \multirow[t]{2}{*}{ Village } & \multirow{2}{*}{$\begin{array}{l}\text { Total } \\
\text { Population }\end{array}$} & \multicolumn{2}{|c|}{ No. of Houses } & \multirow{2}{*}{$\begin{array}{l}\text { Govt. Establishment \& } \\
\text { Private Property }\end{array}$} \\
\hline & & & Kucha & Pucca & \\
\hline 1 & ITAPARA & 1724 & 134 & 121 & $\begin{array}{l}\text { Mandir-7, School-4, } \\
\text { Panchayet Office-1 }\end{array}$ \\
\hline 2 & BILA & 676 & 118 & 44 & $\begin{array}{l}\text { Mandir-6, School-1, Health } \\
\text { Centre-1 }\end{array}$ \\
\hline 3 & AMDIHA(PART) & 240 & 10 & 53 & $\begin{array}{l}\text { Mandir-1, School-1, PHE } \\
\text { Tank- 1+Water Filter Plant }\end{array}$ \\
\hline 4 & AMLALA(PART) & 162 & 12 & 20 & Mandir-2 \\
\hline 5 & KHOIRABAD & 900 & 100 & 60 & Mandir-1,School-1 \\
\hline
\end{tabular}




\begin{tabular}{|c|l|r|r|r|l|}
\hline 6 & NANDAI+TALKANALI & 448 & 77 & 14 & Mandir-2, School-1 \\
\hline 7 & PAKURIA & 88 & 20 & 2 & \\
\hline 8 & KENJIA & 350 & 45 & 25 & $\begin{array}{l}\text { Mandir-1, School-1, Health } \\
\text { Centre-1 }\end{array}$ \\
\hline 9 & BARDANG & 1749 & 178 & 143 & Mandir-7, School-1 \\
\hline 10 & DANGALPARA(KESARDI) & 142 & 25 & 10 & Mandir-1, School-1 \\
\hline 11 & MAJHI BASTEE-2 & 200 & 42 & 3 & \\
\hline & TOTAL & 6679 & 761 & 495 & \\
\hline
\end{tabular}

Source: Author's analysis, based on field survey carried out in 2018

As per the table 1 more than 1000 hectares of land has been lost over a span of 20 years in only two blocks in Asansol subdivision and Burdwan district. The effect of land loss on agricultural activities may however be more objectively estimated through the statistics of number of persons employed in agriculture and their migration if any. The decrease of cultivable land is clearly visible in Raniganj coalfield is estimated $17.40 \%$. The matter has been discussed in subsequent paragraphs.

It is a difficult task to estimate the number of farmers and agricultural workers displaced or affected due to land loss and land degradation. From the relevant data it is revealed that in Satgram area alone the number of cultivators decreased from 4103 in 2000 to 1753 in 2017, which means a decrease in cultivators of 2350 in a span of 10 years. It may be noted that in Asansol, Salanpur and Katras development blocks (all located in coalmining area) there have been a decrease in number of persons employed in agriculture by approximately 3300, 3500 and 2600 respectively over a period of ten years, there has been increase in agricultural employment in non mining areas. In actual terms, it is not that a particular group of agricultural labours become completely redundant, but the partial loss of occupation pervades in the agricultural labour class. The effect of such partial loss of occupation becomes more intense because in the Raniganj and Jharia coal belt the people are subsisting on agriculture have no means of augmenting their income by keeping cattle or by fish culture as these occupation have now become rare in the coal belt (Randeira, 2003).

The tendency of indigenous population to shift from agricultural activities is being accentuated due to the presence of migrant labours employed in coal mines and having steady income. The unemployed men flock of these families tends to take up the job of 'share cropping' replacing the traditional share cropper or agricultural worker in the process. If this trend continues and become dominant the profile of agricultural community in the coalfield will undergo a havoc change.

\section{Displacement due to Mining Activities in South Bengal}

Out of total villages, due to coal mining hazards, local administration has been proposed to Re-settle fifteen villages as rehabilitation in the adjacent area. This development will increase Socio-economic benefits to the local inhabitants by way of direct and indirect employment, improvement in infrastructure and escalation in ancillary facilities in those villages. Before displacement $25 \%$ labors were farmers, but after displacement it is reduced to $12 \%$ because due to coal - mining activities, agricultural lands are lost. For loss of 2 acres of agricultural land, 1 (one) employment was provided in ECL as compensation.Thus farmers have now turned into employees of Coal industry. $78 \%$ of villagers responded that they support coal mining industry in this area but remaining $22 \%$ responded in negative. $92 \%$ of villagers lived in this village since birth. So, they are strongly bonded with their village. Villagers agreed for displacement as coal mining is associated with Industrial development of our country but on personal ground no one wants to leave their parental home and birth place. All villagers had very strong bondage with their neighbor as they lived together since birth. The growth of mining activities in the region has acted as the most powerful stimulant in the emergence of new industries and in the growth of new urban centers. 
These in turn have caused further social alienation of indigenous people's territory and their displacement (Singh, 2011).

\section{Degradation of Land due to Mining Activities in West Burdwan district}

In India, major coal fields are located in state of West Bengal, Bihar and Orissa. Raniganj coal field is having a large number of coal mines in terms of quality of coal and extraction of. There are more or less 800 coal mines in India. India occupies third position in the world in the field of coal excavation. Raniganj coal belt is a significant coalfield situated in Damodar river valley. State of West Bengal has 2512.4 billion ton total coal reserve. Total coal reserve up to six hundred meter depth is 35 billion tones, about 23 billion tones in West Bengal alone. The total extractable reserve of coal has been accessed as 8 billion tonnes; this includes 6 billion tones in West Bengal \& 2 billion in Jharkhand. Before coal was discovered in Raniganj coalfield in the late 18th century, this area was a forested district popularly known as Jangal Mahal. Land subsidence \& Land degradation rose due to coal mining activities. It impacts the capacity of soil which results the failure of crops. In Asansol $8.75 \%$ and in Raniganj coalfield $26 \%$ people suffered due to land subsidence. Their farming lands are now converted in to fallow land/barren lands. The villages like Phatehpur, Barachak, Egara \&Narsamuda villages are severely affected by land subsidence. Rice, wheat\& Pigeon pea are major crops grown in this area. Rise in coal mining excavation activities in the area converted farming land in to fallow/barren \& degraded lands. Area under land subsidence is increasing and becoming vulnerable due to underground coal mining. As a result of this water holding capacity of farming \& other land is reducing (Walker, 2011).

\section{Absolute Power to take over Private Land}

The laws of acquisition of land empower the state to compulsorily acquire private property. The authority is rooted in the juristic notion of 'eminent domain' which justifies sovereign prerogative to exercise control over natural resources in its territory. The rights and interests of individuals or groups exist only with its authority. This implies that the citizen holds property subject always to the right of the state to take it for a socially desirable purpose. As a consequence, the right of a person or a community to resist state action for compulsory acquisition of land is obliterated. This legal rationality of 'eminent domain' makes state immune to any challenge to its action in the courts. This skewed balance between state power and individual/community rights is considered untenable in a democracy as its consequences are patently unjust and, therefore, unacceptable to citizens. There has therefore been a strong demand to abandon 'eminent domain' and to acquire land only with the consent of its holder (Walker, 2011).

\section{Arbitrariness in Defining 'Public Purpose'}

The moral imperative in acquisition of land for a 'public purpose' implies that the acquisition is justified only when the prospective use of land serves the interest of larger society and not of an individual or a group or an entity. As the law itself does not spell out the definition of 'public purpose' it has been left to the executive to decide which activity would justify this label for exercise of this power. The courts have upheld the judgement of the government in this regard. This flexibility has permitted the government to enlarge the scope of acquisition without facing any judicial scrutiny and has enormously increased the quantum of an acquisition of land, lifesupporting assets of people with no consideration for its deleterious consequences on their dignified survival. A drastic limit to the use of 'public purpose' through a tighter and precise definition has been sought along with the right of the affected persons to challenge the propriety in the court of law (World Bank, 2007).

\section{Rehabilitation of Displaced Persons}

The most glaring tilt in favour of the state lies in the law failing to cast any responsibility on it to provide a satisfactory rehabilitation of those displaced by it as its integral feature. The moral responsibility of the state towards these persons is not discharged by mere payment of compensation since acquisition of land causes their impoverishment and inmiserization. The state practice and judicial oversight have also failed to respond to this imperative thereby making law as an instrument of destitution. This has highlighted the need for a legal entitlement to a strong and comprehensive rehabilitation and resettlement of displaced persons as a precondition to acquisition of land (Levien, 2011).

\section{Multiplicity of Laws}

There is a virtual jungle of laws with as many as 16 central laws and equal number of state laws dealing with land acquisition. These laws are not uniform in processes and entitlements they 
provide. These laws cater to different sectoral activities for which land is acquired. As a result, different laws may operate in the same area affecting the same people depending on the situation. This diversity of laws completely disempowers people and emasculates their ability to respond to their processes. Their operation only serves to extinguish any possible right of the affected people to raise objections to the acquisition of land and put up their claims of compensation, and smoothen the process of acquisition using force where they resist them. Government has not even tried to harmonize them so as make the beneficial provisions applicable to all, not even by an executive order. The result is virtual expropriation of people's land. A single law to accommodate all purposes and contingencies is considered adequate (Sharan, 2009).

\section{Centrality of Bureaucracy}

The entire procedural frame of land acquisition gives a pivotal role to the bureaucracy. Two levels of bureaucracy are involved in it - the collector in the district and the land revenue department in the secretariat. It is the satisfaction of the state exercised through its agent in the district, i.e., the collector, which triggers the process leading to unhindered acquisition of land and thereafter the resettlement of displaced persons, the process as collector centric at every stage of acquisition process. The second level is the state secretariat which sanctions the proposal for land acquisition, and approves the compensation award formulated by the collector. The government at this level also decides the contours of the resettlement policy.

Given this centrality of bureaucracy, the orientation of officials involved in decision-making is important. This orientation is tilted in favor of the project backed by government and disregards the views and interest of those adversely affected by it. It provides no space for participation in this decision-making to make the outcome less traumatic and painful. This explains the demand for a participatory made of acquisition to democratize the process of acquisition and humanizes its outcome (Sharma, 2003).

\section{Privileging Land Acquisition Law over other Laws}

The law of land acquisition is only one of the laws impinging on the transfer of land. The Constitution of India contains special provisions for protection of tribal communities, one of which relates to restrictions on transfer of land from tribal land holders to non-tribal persons. The 'Samatha judgement' of the Supreme Court has laid down a framework of restrictions from transferring tribal land to industry or mining or for any other alternative use in Scheduled Areas. The Central Government has also enacted the Panchayats (Extension to Scheduled Areas) Act, 1996 which mandates consultation of the concerned Gram Sabha on the proposal relating to acquisition and transfer of land in schedule V area. Similar provision exists in respect of Schedule VI area. Recently, the government has enacted Scheduled Tribes and Other Traditional Forest Dwellers (Recognition of Rights) Act, 2006. These laws are ignored while processing land acquisition proposals (Sharan, 2009). The government thus becomes instrumental in violation of these laws by privileging land acquisition law over them thereby contributing to the disintegration and destitution of the tribal communities. The need for eliminating this conflict by making land acquisition law consistent with protective laws relating to the tribes has been asserted (Morris, 2009).

\section{Market Fundamentalism of Compensation Assessment?}

In the matter of award of compensation, the law is centred on 'market assessment' as the fair and adequate parameter of the value of land. But the market is a thoroughly inadequate instrument of determination of value of land. It is not neutral to the parties involved in transaction and is manipulated by powerful economic entities and social pressures. The purchase and sale transactions are also distorted by undervaluation of land to avoid tax liability or to conceal unearned income. In the case of tribal land, the legal restrictions on its transfer results in absence of market transactions and/or, where transactions exist, highly undervalued amount in them. The market also cannot assess the 'value' of land for individuals and social groups with unequal socio-economic status and vastly different and even conflicting cultural values. Also, land being an asset used for livelihood has a different value than other commodities exchanged in the market. Besides, vesting power of valuation in the government which is an interested party in the acquisition process makes the outcome unfair to the affected persons. A more acceptable formulation which accommodates different strands of thought and does justice to the different interests of those affected has been sought (Polanyi, 1944). 


\section{Undemocratic Practice}

Besides the provisions of law, the undemocratic practice in enforcement of the law compounds the misery of the affected persons.

Some of the features of this practice are discussed below:

Control over Information: The Land Acquisition Act, 1894 does provide for mandatory consultation of affected persons in the acquisition proceedings at two stages. The first stage is when a preliminary notification is issued about intention to acquire land. The second stage is when affected persons are asked to file compensation claims. The first consultation is undertaken by issue of notice in two newspapers circulating in the locally, its publication in the official gazette and placing the substance of it in convenient places. But the information contained in the preliminary notification is too meager and sketchy to permit interested persons to have a clear knowledge about the project, its present and future, its rationale for selecting the site, the magnitude of displacement it would cause and specific area in villages which would be affected. There is an undercurrent of information squeeze and control, and urgency to rush through the process of acquisition. There has therefore been insistence on acquisition of land only with informed consent of the affected persons (Goswami, 2013).

\section{Environmental and Social Impact Assessment}

A radical change of land use after acquisition has serious environmental implications which are never taken into account while taking a decision on the project, resulting in environmental degradation, and loss of biodiversity. Similarly, projects entail large scale displacement of people leading to social destabilization, impoverishment and emotionally disturbed conditions.

Neither the government nor the acquisition authority direct the project agency to get environmental and social impact assessment carried out so as to realistically assess negatives of the project in the absence of an express provision to this effect in the law. This underlines the demand for such an assessment by an independent agency as a pre-condition to initiation of land acquisition proceedings so that information based on it could form the basis for a decision on whether the project should be cleared the scale and contours of and rehabilitation of people and restoration of environment, that would be needed if the project is cleared (Levien, 2011).

\section{Multiple Displacements:}

The law does not take into account the phenomenon of multiple displacements and therefore provides no relief for it. The callousness in effecting multiple displacements of the same persons is caused by failure to anticipate further development of the area and undertake permanent resettlement of the displaced persons at a safe site after the first displacement. The alternatives to avoid it are also not seriously explored (Lahiri-Dutt, 2007).

\section{Property-Centric View of Compensation}

The connotation of compensation in the law has a limited meaning. It is equated with the value such land would fetch in terms of money when sold or the notional value of land in the market. Additionally, an amount of thirty per cent of that compensation as solatium is paid to reduce injustice caused by the vagaries of the market. The compensation amount so paid does not make up for the whole range of losses, social, cultural and economic, resulting from forced eviction. Social and cultural losses relate to, among others, social disruption loss of community networks and emotional trauma suffered by the affected people. No value is attached to these losses in the computation of compensation. Economic loss resulting from acquisition of land is conceived in terms of income derived from its cultivation and does not include in it the loss of access to common property resources the benefits of which cover a sizeable part of the income of the poor (Thakur, 2008).

\section{Outdated Land Records}

The acquisition process proceeds on the basis of land records which contain the details of land and persons who have interests in land. The land acquisition proceedings can suffer from serious errors and can cause grave injustice if land records are not up to date. The land records across the country are outdated. They do not reflect the transfer of land, changes in land use and those emerging from court cases, mutual settlements, encroachments, alienation of land and tenancies. These results in deprivation of entitlements to those who in the absence of updated land records on this account fail to get compensation or other benefits. The mandatory updating of land records has therefore been advocated before initiating land acquisition proceedings (Deininger, 2011). 


\section{Change of 'Public Purpose'}

Land is acquired for a 'public purpose'. The nature of 'public purpose' is usually declared in the preliminary notification issued for acquisition. But after the land has been acquired, quite often, the project/government utilize the land for some other 'public purpose' which is a violation of the law. But the courts have not found fault with this change of use. There is no provision in the law that such a change would require reprocessing the case of acquisition and declaration of a fresh award. This deficiency shows that the declaration of 'public purpose' was arbitrary and deprives the affected persons of the opportunity to raise objections and seek a fresh award on the basis of prevailing 'market value' of the land. The insertion of a provision for reprocessing the proposal of acquisition and declaration of a fresh award would put a check on indiscriminate use of 'public purpose' for acquisition of land (Guha, 2006).

\section{Shoddy Relocation}

The acquisition authority takes a great deal of interest in acquiring land for the project most expeditiously but the same interest is not shown in developing the resettlement colony to which the displaced persons are hurriedly shifted. The result is a shoddy relocation which compounds the misery of people who have already lost livelihood and are going through a traumatic transition. The relocation sites lack even elementary amenities forcing people either to spend their meagre compensation amount on improving their living conditions or to migrate. They also face hostility of the host communities in accessing resources if they are shifted to an existing village. This explains insistence on benchmarking the minimum conditions of infrastructure and facilities in the resettlement colony before displaced persons are shifted to it (Corbridge, 2004).

\section{Displacement as a Problem}

The problem of displacement is not merely economic; it is also a socio-cultural problem because it disturbs a network of social relationships supporting an ethos and a way of life. It affects the entire gamut of traditional activity and an established social order. It forces people to adopt new ways of occupational activities and an unknown environment. As such, the process is akin to 'replacement' in a new location. The displaced people are forced to change their social patterns, without getting any compensation for social costs and, thus, they are under pressure, causing a situation of socio-cultural stress (Goswami, 2013).

\section{Absence of Participation}

The only safeguard provided in the law against arbitrary action acquisition of land is the frame of rule of law and the quasi-judicial nature of its proceedings. The acquisition process provides a modicum of participation to persons likely to be affected. The participation is, however, limited to raising objections/contesting the proposal of acquisition and, later, to submission of views on the quantum of compensation sought. This participation carries no value as the acquisition authority is tilted in favor of the project and is guided by the views of the government. It brushes aside affected people's opposition to acquisition. Courts have also declined to undertake a judicial review of this issue (Sharma, 2003). There is also absence of participation in defining and establishing rights and determining the design of compensation (Stuligross, 2010). The provisions of participation are also outdated as the panchayats are not involved in dissemination of information and seeking views of the people affected out. Thus, the majority of those affected by acquisition have neither access to information required nor have the capacity and resources to 'participate' in the proceedings. Besides, formal records of acquisition proceedings contain very limited information on decisions taken and factors influencing the process of making these decisions. There is minimal effort to ensure reach of information to the affected persons and create an enabling environment for them to express their views much less to have a re-look at the proposal for acquisition in the light of concerns expressed by them. Effective and institutionalized participation affected persons with adequate information at all stages of land acquisition and rehabilitation has therefore been sought (Upadhyay, 2009).

\section{Bias against people}

The operation of law as reflected in the practice of officials handling acquisition and relocation arrangements carries an unmistakable bias against the affected persons resisting acquisition of their land. They are clearly committed to expedition's acquisition of land and any opposition to it is perceived as anti-development activity which warrants no empathy. Some instances of this bias can be observed from this following (Goswami, 2013). 


\section{Lack of concern for rehabilitation of displaced persons}

In the absence of an obligation in law for the state to rehabilitate and resettle affected person, the concerned governments have resorted to most minimum amenities required for shifting the displaced persons after evicting them from the land acquired. Even the limited adhoc assurances given to the displaced about rehabilitation to neutralize their opposition to the project have been diluted or reversed in the course of implementation. Government feels that payment of compensation, a provision of a small house and a minimum of infrastructure at the resettlement site is sufficient to discharge its obligation. This has left behind a trail of devastation. The affected persons are left to face an uncertain and bleak future. This deficiency is responsible for increasing hostility of the affected persons to acquisition proposals. A legally enforceable commitment to provide comprehensive rehabilitation and resettlement to all the displaced persons who should include, besides financial assistance for subsistence during the transition period, alternative land, employment, residential house, skill development, infrastructure facilities and social amenities has been sought to prevent this catastrophic consequence (Choudhary, 2009).

\section{Resettlement and Rehabilitation}

Resettlement of the displaced people is one-time relocation at a new site with payment of compensation for the land acquired and without other support such as jobs, training and welfare inputs to resettle in a new society and economic situation. Rehabilitation focuses on social and cultural factors and attempts to rebind the dispossessed livelihoods of the displaced and projectaffected people. It is not limited to economic compensation but, goes beyond to include welfare approach.

Rehabilitation is more often understood as an economic rather than a psycho-sociological phenomenon resulting from displacement. It is normally perceived as a 'planned change effort'. In a strict sense, it implies that, the overall objective of the change is to restore the situation to its original condition (Franks, 1991). The nature of rehabilitation is quite different from other developmental processes. All developmental efforts imply planned change to improve existing conditions, whereas rehabilitation is designed to restore the status quo. This makes it imperative to understand the term rehabilitation in a much wider perspective, and its components, which make it different from other developmental processes (Sinha, 2006). However, rehabilitation should go beyond maintaining of the status quo and adopt welfare approach to improve the standard of living of the displaced population (Harvey, 2003).

\section{Coercion to force people to agree to acquisition}

Officials are, as a rule, hostile to any expression of resistance against proposals of acquisition. They try to suppress this opposition in various ways. They connive at the manipulative tactics used by the requiring agencies to coerce resisting villagers into agreeing to the land acquisition proposal. Mine owners, for example, obtain mining lease on the government land adjacent to the private land of people who are unwilling to its acquisition and then frighten them by continuous blasting operations on it. Project agencies dealing with the construction of dams use the threat of submergence to hasten their eviction (Jewitt, 2008). There have been cases when officials of industrial projects have polluted drinking water sources on which people of the village depended to break their resistance to acquisition. At times they use divisive tactics by favoring a few displaced persons with extra benefits to weaken the united opposition to the project. The project officials are known to employ intermediaries and muscle men to threaten, assault leaders/local participants and involve them in criminal cases to intimidate opponents of project. The district officials are known to keep opponents of the project out of public hearing so as to present a manufactured consent in its favor. The victims get no help from the government agencies in these situations. Adequate safeguards are needed to check such practices (ACHR, 2007).

\section{Conclusion}

The mining activities induces the growth should be a holistic notion that encompasses the progressive development in the quality of individual's life in terms of food, clothing and shelter and the environment for a healthy living with rising longevity of life and happiness. In West Bengal the development process reveals the indications and effects of widening inequalities between the "haves" and "have-nots" and the growing deprivation of the vulnerable and marginalized sectors of the population. There are very small trickle down effects of the economic development associated 
with this model of growth. But when it is necessary to undertake development projects that engage the displacement of communities, it is indispensable that these projects obtain the legal permission and support of the people who are affected and that in return for giving up their land and homes they receive priority if not exclusive rights to the benefits emanating from these projects (Singh, 2003).

The impact of coal mining on the local public of eastern coal mining region (ECL) of West Burdwan district exemplifies accumulations by dispossession occurring as a result of the new mining policy made by the government in the age of globalization. The indispensable characteristic of growth by dispossession is the replacement of long standing conventional forms of production by new market-based forms of productions and consumptions. In the Sonepur Bazari, Ukhra mining area, accumulations by dispossession is enacted through the process of displacement and force integration of the tribal as well as farmer population using indirect force and conversion of different forms of property rights by the weaknesses of existing laws and also by the $\mathrm{R}$ and $\mathrm{R}$ policies (Singh, 2010). It also creates a propensity towards polarisation. The adivasi (Tribe) communities of ECL of West Bengal have emerged in their current state of dispossession through stages. The present stage of physical dispossessions can be understood as the final stage with fundamental changes of traditional ways of subsistence level cultivation to non-agricultural informal sector. This is one of the main characteristics of industrial development.

\section{References}

Asian Centre for Human Rights, 2007 - Asian Centre for Human Rights (2007). India's Failed National Rehabilitation and Resettlement Policy, 2007. [Electronic resource]. URL:http://www.achrweb.org/Review/2007/198-07/html

Bhushan, Hazra, 2008 - Bhushan, C., Hazra, M.Z. (2008). Mining in the Sates: Jharkhand and West Bengal in Rich Lands, Poor People: Is 'Sustainable' Mining Possible? State of India's Environment: Sixth Citizens' Report (New Delhi: Centre for Science and Environment).

Choudhary, 2009 - Choudhary, T. (2009). Use of Eminent Domain: Process and Its Critique in India Infra-structure Report 2009: Land - A Critical Re-source for Infrastructure, 3iNetwork, OUP, pp 75-76. [Electronic resource]. URL: http://www. iitk.ac.in/3inetwork/html/reports/IIR2009/ IIR_2009_Final_July\% 2009.pdf

Corbridge, 2004 - Corbridge, S. (2004). Competing Inequalities: The Scheduled Tribes and the Reservation Sys-tem in India's Jharkhand in S Corbridge, S Jewitt and S Kumar (ed.), Jharkhand: Environ-ment, Development and Ethnicity (New Delhi: Oxford University Press), pp 175-202. Original-ly published in Journal of Asian Studies, 59(1).

Deininger, Derek, 2011 - Deininger, K., Derek B. (2011). Rising Global Interests in Farmland: Can It Yield Sustainable and Equitable Benefits, Washington DC, World Bank.

Guha, 2006 - Guha, A. (2006). Dispossession of Peasants by Industrial Projects in S Jain and M Bala (ed.). The Economics and Politics of Resettlement in India (Delhi: Pearson Longman), pp. 155-73.

Goswami, 2013 - Goswami S. (2013). Need for Clean Coal Mining in India. Environmental Research, Engineering and Management, 4:66: 79-84. Press).

Harvey, 2003 - Harvey, D. (2003). The New Imperialism (Oxford: - Oxford University

Jewitt, 2008 - Jewitt, S. (2008). Political Ecology of Jharkhand Conflicts. Asia Pacific Viewpoint, 49(1): 68-82.

Jha-Thakur, Thomas, 2008 - Jha-Thakur, U., Thomas F. (2008). Are Open-cast Coal Mines Casting a Shadow on the Indian Environment. International Development Planning Review, 30(4), Vol. 30(4): 441-59.

Lahiri-Dutt, 2007 - Lahiri -Dutt, K. (2007). Illegal Coal Mining in Eastern India: Rethinking Legitimacy and Limits of Justice. Economic \& Political Weekly, XLII (49), 8 December.

Lahiri-Dutt, Nesar, 2012 - Lahiri-Dutt, K., Nesar, A. (2012). Considering Gender in Social Impact Assessments in Frank Vanclay and Ana Maria Este-ves (ed.). New Directions in Social Impact As-sessments: Conceptual and Methodological Ad-vances (Cheltenham: Edward Elgar).

Levien, 2011 - Levien, M. (2011). Rationalising Dispossession. Economic \& Political Weekly, Vol XLVI, No 11, 11 March. 
MMSD, 2002 - MMSD (2002). Breaking New Ground: The Report of Mining Mineral and Sustainable Development Project. [Electronic resource]. URL: http://pubs.lied. org/pdfs/8084IIED. pdf?lastviewed on 20 January 2011.

Morris, Ajay, 2009 - Morris, S., Ajay Pandey (2009). Land Markets in India: Distortions and Issues in India Infrastructure Report, 2009: Land - A Critical Resource for Infrastructure, IDFC (New Delhi: Oxford University Press).

Polanyi, 1944 - Polanyi, K. (1944). The Great Transformation: The Political Economic Origins of Our Time (Boston: Beacon Press).

Randeira, 2003 - Randeira, S. (2003). Glocalisation of Law: Environmental Justice, World Bank, NGOs and the Cunning State in India. Current Sociology, 51(3-4).

Sharan, 2009 - Sharan, $R$. (2009). Alienation and Restora-tion of Tribal Land in Jharkhand in Nandini Sundar (ed.). Legal Grounds: Natural Resourc-es, Identity, and the Law in Jharkhand (New Delhi: Oxford University Press).

Sharma, 2003 - Sharma, M. (2003). Implications of the CBA Act and Coal India R \& R Policy on DPs and PAPs of Raj-mahal Opencast Coal Mine Expansion Project, with focus on Necessity for Gender-Sensitive Rahabilitation Programme Development, Re-port Submitted as a project, Indira Gandhi National Open University, New Delhi.

Singh, Kaliappa, 2003 - Singh, K., Kaliappa, K. (2003). A Decade of Economic Reforms in India: The Mining Sector, Resources Policy, 29: 139-51.

Singh, 2010 - Singh, R. (2010). Ending Misuse of Land Acquisition Act in the Economic Times, 18 November [Electronic resource]. URL: http://economictimes.indiatimes.com/opinion/comments-analysis/Ending-misuse-of-land -acquisition-laws/articleshow/ 6944908.cms, viewed on 8 December 2018.

Stuligross, 2008 - Stuligross, D. (2008). Resources, Representation, and Authority in Jharkhand, India. Asia Pacific Viewpoint, 49(1): 83-97.

Szablowski, 2010 - Szablowski, D. (2010). Operationalising Free, Prior, and Informed Consent in the Extractive Industry-Sector? Examining the Challenges of a Negotiated Model of Justice. Canadian Journal of Development Studies, 30(1-2): 111-30.

Upadhyay, 2009 - Upadhyay, C. (2009). Law, Custom and Adivasi Identity: Politics of Land Rights in Chhotanagpur in Nandini Sundar (ed.). Legal Grounds: Natural Resources, Identity, and the Law in Jharkhand (New Delhi: Oxford University Press), pp. 30-55.

Walker, 2011 - Walker, K. (2011). Neoliberalism on the Ground in Rural India: Predatory Growth, Agrarian Crisis, Internal Colonisation, and the Intensification of Class Struggle. Journal of Peasant Studies, 35(4): 557-620.

World Bank, 2007 - World Bank. Jharkhand: Addressing the Challenges of Inclusive Development, Washington DC, World Bank, 2007. 